\title{
Ylirajaiset venäläiset nykykirjailijat Suomessa
}

Artikkelini keskittyy kirjallisuuden ylirajaisuuteen ja erityisesti venäjänkielisiin kirjailijoihin, jotka asuvat kotimaansa ulkopuolella ja kirjoittavat muulla kuin äidinkielellään. Käsittelen kahta Suomessa asuvaa venäjänkielistä kirjailijaa, Zinaida Lindéniä ja Polina Kopylovaa, jotka kirjoittavat kaunokirjallisia tekstejä ruotsiksi ja venäjäksi sekä suomeksi ja venäjäksi. Tarkastelen, miten he lähestyvät monikielistä luomisprosessia, mitä heille merkitsee kirjoittaminen kahdella kielellä ja miten se heijastuu heidän kaunokirjallisissa teksteissään. Tarkasteluni pohjautuu kirjallisuuden ylirajaistumiseen liittyvään tutkimukseen ja siinä esiin nostettuihin ajatuksiin kansallisten kirjallisuuksien monikielisyydestä ja kulttuurienvälisyydestä. Tutkimusaineistona ovat kirjailijoiden kaunokirjalliset tekstit sekä kirjailijahaastattelut.

Marja Sorvari

Artikkelini liittyy kirjallisuuden ylirajaistumisen ${ }^{1}$ tutkimukseen ja siinä esiin nostettuihin kysymyksiin kansallisten kirjallisuuksien monikielisyydestä ja kulttuurienvälisyydestä. Tutkimuskohteenani ovat erityisesti kirjailijat, jotka asuvat synnyinmaansa ulkopuolella tai ovat osa kansallista, kielellistä tai kulttuurista vähemmistöä. Tällaiset kirjailijat kirjoittavat usein muulla kuin äidinkielellään: joko uuden kotimaansa enemmistön puhumalla tai virallisella kielellä. Nämä kirjailijat ovat erityisesti parin viime vuosikymmenen aikana saaneet yhä enemmän huomiota kirjallisuudentutkimuksessa. Tarkasteluni kohdistuu venäjänkielisiin nykykirjailijoihin, Zinaida Lindéniin ja Polina Kopylovaan, jotka asuvat Suomessa ja ovat kirjoittaneet kaunokirjallisia tekstejä äidinkielensä lisäksi myös ruotsiksi (Lindén) ja suomeksi (Kopylova). Artikkelissani tarkastelen, miten monikielisyys ilmenee heidän teksteissään ja mitä muulla kuin äidinkielellä kirjoittaminen heille merkitsee. ${ }^{2}$

Ylirajainen kirjallisuus ei ole uusi ilmiö, vaan läpi kirjallisuuden historian kirjailijat ovat kirjoittaneet vierailla kielillä (Kellman 2000, 7). Esimerkiksi 1900-luvun tunnetuimpia ylirajaisia kirjailijoita ovat Vladimir Nabokov, Samuel Beckett ja Joseph Conrad. Steven 
G. Kellman nosti muulla kuin äidinkielellä kirjoitetun kirjallisuuden omaksi tutkimuksen kohteeksi teoksessaan The Translingual Imagination (2000), jossa hän käsittelee laajasti eri kielikonteksteissa syntynyttä ylirajaista kirjallisuutta ja ylirajaisuuden merkitystä taiteellisessa luomistyössä. Viime vuosina kielirajat ylittävä kirjallisuus on kiinnittänyt tutkijoiden huomion kysymyksiin hybrideistä identiteeteistä, monikielisyydestä ja kulttuurillisista välitiloista (Kellman 2000; Nordin, Hansen \& Zamorano 2013; Steinitz 2013). ${ }^{3}$ Näin on tapahtunut myös venäläisen kirjallisuuden tutkimuksessa, jossa aiemmin vakiintunut termi "emigranttikirjallisuus" on väistymässä:

Omana aikanaan nämä kirjailijat [Vladimir Nabokov, Joseph Brodsky, Irène Nemirovsky, Elsa Triolet] luettiin pakolais- tai emigranttikirjailijoiksi; nykyisin heidän teoksensa usein nähdään kuuluvan siirtolaiskirjallisuuteen, diaspora- tai maailmankirjallisuuteen. Tämä heijastaa muutoksia kirjallisuudentutkimuksen kentällä ja etenkin globalisaation ja lisääntyneen muuttoliikkeen tuomia muutoksia todellisessa maailmassa. (Hansen 2018, $113-114.)^{4}$

Sen lisäksi että muutoksia on tapahtunut kirjallisuudentutkimuksen lähestymistavoissa, muulla kuin äidinkielellä kirjoitettu kirjallisuus on tänä päivänä yleisempi ilmiö kuin esimerkiksi viisikymmentä vuotta sitten (Hansen 2018, 113). Kasvavasta kiinnostuksesta venäläistä kulttuurienvälistä kirjallisuutta kohtaan ja sen merkityksestä kertoo myös runsas viimeaikainen tutkimus. $^{5}$

Suomessa venäjänkielisiä kirjailijoita on ollut 1800-luvun alusta lähtien ja Suomeen syntyi vuoden 1917 jälkeen oma emigranttikirjailijoiden yhteisö, joka toimi melko erillään muusta Suomen kirjallisuuden kentästä (Baschmakoff \& Leinonen 2001; Latomaa 2010, 56). ${ }^{6}$ Sen sijaan 1990-luvulla Suomeen muuttaneista venäjänkielisistä kirjailijoista monet ovat menestyneet ja löytäneet paikkansa Suomen kirjallisella kentällä, kuten Venäjän Karjalasta kotoisin oleva Arvi Perttu, leningradilaissyntyiset Zinaida Lindén ja Polina Kopylova sekä Suomessa toimivan venäjänkielisen kirjallisuuslehti Literarusin päätoimittaja ja kirjailija Ljudmila Kol. Suomessa asuu nykyisin lukuisia venäläistaustaisia kirjailijoita, jotka kirjoittavat ja julkaisevat venäjäksi ja suomeksi. ${ }^{7}$

Tarkastelen tässä tarkemmin kahden Suomessa asuvan venäjänkielisen kirjailijan, Zinaida Lindénin ja Polina Kopylovan, kaksikielistä tuotantoa ja sitä, miten monikielisyys ja kulttuurienvälisyys ilmenevät heidän teksteissään. Pohjaan tarkasteluni kirjallisuuden ylirajaistumiseen liittyvään tutkimukseen, jossa on tuotu esille muuttuneita käsityksiä "puhtaasta" äidinkielestä, "alkuperästä" ja kääntämisestä. Tutkimusmateriaalina käytän Lindénin ja Kopylovan kaunokirjallisia tekstejä, esseitä ja haastatteluja. Lopuksi tuon yhteen analyysissa esiin tulevia näkökulmia siihen, miten ylirajainen, monikielinen kirjallisuus purkaa kirjallisuuden ja kansallisuuden välisiä vakiintuneita kytköksiä (Grönstrand et al. 2016, 27).

\section{Kirjallisuutta äidinkielen "tuolla puolen"}

Vieraalla kielellä kirjoittaminen haastaa käsitystä siitä, että kirjailija voi ilmaista itseään parhaiten vain omalla äidinkielellään. Ajatus äidinkielestä "alkuperäisenä", oikeana ja aitona itseilmaisun välineenä on kytkeytynyt tiiviisti modernien kansallisvaltioiden syntyyn: ajatus omasta kansasta ja sen omasta kielestä pitää sisällään ajatuksia luonnollisesta alkuperästä, tunnesitein juurtuneesta yhteydestä, mitä nimitys "äidinkieli" myös ilmentää. (Grönstrand 
2014; Yildiz 2012, 203-204.) Kansan- ja äidinkielinen kirjallisuus on kiistatta ollut keskeinen elementti, kun on luotu ideaa yhtenäisestä kansakunnasta, ja se on edelleen lähtemätön osa sitä. Ajatus yhdestä, "puhtaasta" äidinkielestä kuitenkin häivyttää "kansan" ja kirjallisuuden monikulttuurisuutta ja monikielisyyttä: kansalliset kirjallisuushistoriat ovat harvoin tuoneet esille kansalliskirjailijoiksi nimettyjen kirjailijoiden tuotannosta muita kuin valtakielellä kirjoitettuja teoksia. (Grönstrand 2016.)

Muulla kuin äidinkielellä kirjoittamista on määritelty englanninkielisellä termillä literary translingualism, ${ }^{8}$ jolle ei ole tarkkaa suomenkielistä vastinetta. Suomen kielessä käytetään muun muassa käsitteitä ylirajainen, transnationaalinen, kulttuurienvälinen ja monikielinen kirjallisuus. Nämä termit ovat merkitykseltään laajempia kuin englanninkielisen termin tarkoittama kirjoittaminen vieraalla kielellä. (Grönstrand et al. 2016, 21-22.) Käsitteillä on myös yhtymäkohtia. Englanninkielisen termin translingualism etuliite trans- on sama kuin englannin kääntämistä tarkoittavassa termissä, translation, ja tarkoittaa "ylitystä", samoin kuin termissä transnationaalinen, jolla viitataan kansojen ja valtioiden rajat ylittäviin ilmiöihin (Grönstrand et al. 2016, 22; Hansen 2018, 114). Käytän käsitettä ylirajainen sen tavallista suppeammassa merkityksessä, mutta käytän myös vaihtoehtoisesti täsmentäviä ilmaisuja kirjailijan ”muulla kuin äidinkielellään" kirjoittamasta kirjallisuudesta.

Äidinkielen vaihtaminen toiseen, vieraaseen kieleen voi olla kirjailijalle keino taiteellisen ilmaisun kehittämiseen, mutta se voi olla myös olosuhteista johtuva valinta. Rita Wilson (2011, 126) huomauttaa artikkelissaan, että kirjailijalla voi olla pakottava syy kirjoittaa muulla kuin äidinkielellään. Hän voi olla poliittisen vainon uhri omassa maassaan, jolloin kirjallisen ilmaisukielen vaihtaminen kotimaan kielestä toiseen antaa suojaa vainoa vastaan. Kielen vaihtaminen voi olla myös ainoa keino päästä toimijaksi uuden kotimaan kirjalliselle kentälle ja osalliseksi sen symbolisesta pääomasta. Kielen vaihtaminen voi lisäksi tarjota uudenlaista ilmaisunvapautta, puhujapositioita ja identiteettejä koskevia keskusteluja, jotka äidinkielellä eivät olisi mahdollisia. (Wilson 2011, 126.) Yasemin Yildiz (2012, 13-14) korostaa, että muulla kuin äidinkielellä kirjoittava kirjailija ei siirrä äidinkieltään sivuun, vaan kirjoittaa ikään kuin sen "tuolla puolen". Tämä "tuolla puolen" kirjoittaminen (engl. beyond) ilmenee erilaisina metalingvistisinä taitoina ja keinoina. Yildiz viittaa Elizabeth Klosty Beaujourin (1989) tutkimukseen siitä, kuinka kaksikielisyys vahvistaa kirjailijan metalingvistisiä taitoja: "Kaksikieliset ovat jatkuvasti tietoisia äänteiden ja merkityksen, merkitsijän ja merkityn välisestä ehdollisesta suhteesta" (Yildiz 2012, 118). Erityisesti äidinkielen ja oman identiteetin välinen "luonnollinen" ja alitajuinen yhteys kyseenalaistuu, ja kielen äänteet, muodot ja yhteydet toisiin kieliin ja niiden äänteisiin tulevat näkyvämmiksi; tietoisuus kielen olemuksesta "kielenä", merkkeinä, tulee selkeämmäksi. ${ }^{9}$

Kirjallisuuden ylirajaistumiseen ja kirjailijoiden työkielen vaihtamiseen liittyy läheisesti ajatus kääntämisestä. Emily Apterin mukaan uuden kotimaansa valtakielellä kirjoittavat siirtolaiskirjailijat hyppäävät kääntämisvaiheen yli ja siirtyvät suoraan "kohdekieleen" jolloin kääntäminen on osa siirtolaiskirjailijoiden kulttuurista (itse-)representaatiota. (Apter 2006, 99.) Kirjailija ikään kuin kääntää äidinkieliseen ympäristöön sijoittuvat, usein omaelämäkerralliset tarinat kirjoittaessaan niistä toisella kielellä. Vieraalla kielellä teoksensa julkaissut kirjailija on voinut myös kääntää tekstinsä myöhemmin omalle äidinkielelleen, kuten Nabokov, joka käänsi romaaninsa Lolita englannista venäjäksi (Wanner 2013; Beaujour 1989). Kun kahdella tai useammalla kielellä työskentelevä kirjailija kääntää oman tekstinsä kielestä toiseen, puhutaan itsekääntämisestä (Hokenson \& Munson 2007, 1). Itsekääntämiseen voi liittyä hierarkkinen valtasuhde "vähemmistökielen" ja "enemmistökielen" tai hegemonisessa 
asemassa olevan valtakielen välillä. Näin oli esimerkiksi Neuvostoliitossa, missä kirjailijat, joiden äidinkieli ei ollut venäjä, käänsivät tekstinsä venäjäksi. Tunnetuin esimerkki tästä on kirgiisikirjailija Tšingiz Aitmatov, joka kirjoitti tekstinsä kirgiisiksi ja venäjäksi. (Wanner 2018, 123.)

Tutkimusalan tärkeän pioneeriteoksen kirjoittanut Beaujour (1989) on todennut, että kääntäminen ja itsekääntäminen ovat monikielisen kirjailijan luovan toiminnan keskiössä ja vaikuttavat siihen olennaisesti. Monet kirjailijat, jotka ovat kirjoittaneet saman teoksen useilla kielillä, ovat kuitenkin torjuneet käsityksen kääntämisestä ja puhuvat käännöksen sijaan tekstinsä kahdesta "versiosta" tai "rinnakkaisista teoksista" (Fitch 1988, 132-133, sit.: Grutman 2009, 259; Gentes 2013, 266; Wanner 2018, 125). Siten he purkavat alkuperäisen tekstin ja käännöksen välille tavallisesti muodostuvaa hierarkkista suhdetta, jossa alkuperäinen on tavallisesti ensisijainen ja käännös toissijainen. Samalla tekijyyteen liitetty auktoriteetti ikään kuin siirtyy käännökseen, josta tulee toinen alkuperäisteos. (Grutman \& Van Bolderen 2014, 324.)

Käsitys kahdesta versiosta tai rinnakkaisista teoksista, eikä alkuperäisestä ja käännöksestä, korostaa luomisprosessin monikielisyyttä pikemmin kuin näkemys kahdesta erillisestä yksikielisestä teoksesta, vaikka ne olisikin julkaistu erikseen ja eri paikoissa. Muulla kuin äidinkielellä kirjoitetun tekstin tapauksessa voi kysymys olla jopa siitä, että vieraalla kielellä kirjoitettu ensimmäinen (julkaistu) versio perustuu jossain määrin kirjoittajan ensimmäisen kielen versioon, kun itsekääntäminen on "samanaikaista". (Grutman 2009, 259.) Eva Gentesin mukaan "[t]ällaisen 'samanaikaisen itsekääntämisen' ollessa kyseessä kirjoittaja liikkuu molempien versioiden välillä edestakaisin ja sisällyttää käännösprosessin luomisprosessiin siten, että molemmat versiot voivat samaan aikaan toimia alkuperäisenä ja käännöksenä” (2013, 273).

Venäjänkielisten siirtolaiskirjailijoiden itsekääntämistä on tutkinut Beaujourin lisäksi viime aikoina Adrian Wanner $(2013,2018)$. Wanner on tutkinut erityisesti venäläis-amerikkalaisten kirjailijoiden itsekääntämistä, ja toteaa, että englannin kielellä kirjoitettuja proosateoksiaan ovat venäjäksi kääntäneet vain kaksi kirjailijaa: Vladimir Nabokov 1900-luvulla ja Michael Idov 1990-2010-luvuilla. Molemmat ovat ensin julkaisseet teoksensa englanniksi ja vasta paljon myöhemmin kääntäneet ne äidinkielelleen, venäjäksi. Kyse ei siis ole "samanaikaisesta" itsekääntämisestä, jossa molemmat versiot syntyvät miltei yhtä aikaa, vaan "peräkkäisestä" kääntämisestä, mikä on haasteellinen ja aikaa vievä tehtävä (Grutman \& Van Bolderen 2014, 324). Molemmat kirjailijat ovatkin kuvanneet oman englanniksi kirjoittamansa tekstin kääntämistä jälkeenpäin venäjäksi hyvin tuskalliseksi ja vaikeaksi prosessiksi (Wanner 2013).

Wanner (2018) on tutkinut myös runouden kääntämistä, mikä ehkä vastoin ennakkooletusta on tavallisempaa venäläis-amerikkalaisten kirjailijoiden keskuudessa kuin proosatekstien kääntäminen. Tämä on hieman yllättävää siksi, että runous lähtökohtaisesti perustuu nimenomaan kielelliseen rytmiin, riimittelyyn ja alluusioihin, joita on vaikea, ellei mahdotonta kääntää muille kielille. Wannerin tarkastelemille runoilijoille itsekääntäminen on keino tutkia minuuden muutosta ajan saatossa sekä muuttuvaa kielellistä ja kulttuurista kontekstia $(2018,136)$. Artikkelissa käsittelemäni Lindén ja Kopylova ovat molemmat myös "kääntäneet" omia teoksiaan, Lindén proosatekstejään ja Kopylova runojaan. Hekin ovat molemmat torjuneet ajatuksen "itsekääntämisestä”. Molemmat kirjailijat näkevät erikieliset versiot alkuperäisteoksina, joiden tekijöitä he ovat.

Heidi Grönstrandin $(2014,122)$ mukaan kirjailijan itse tekemiä käännöksiä usein tutkitaan listaamalla eroavaisuuksia lähtö- ja kohdetekstin välillä, mikä perustuu käsitykseen kahden 
tekstin välisestä dikotomisesta ("originaali ja käännös") suhteesta. Jos otetaan kuitenkin huomioon esimerkiksi erikielisten versioiden syntyminen lähes samaan aikaan toisiinsa vaikuttaen erojen, puutteiden ja lisäysten luettelointi ei välttämättä tee oikeutta itse luovalle prosessille, jossa molemmat versiot ovat "käännöksiä" ja "alkuperäisiä". Voidaanko tällöin määritellä, kumpi versio on alkuperäinen, kumpi käännös? Alkuteksti vai käännös -dikotomian sijaan Jan Walsh Hokenson ja Marcella Munson $(2007,4)$ esittävät, että tarkasteltaisiin tekstien duaalisuutta, limittyneisyyttä ja kulttuurienvälisyyttä. Pohdin seuraavassa, miten kirjailijat toteuttavat monikielistä luomisprosessia ja miten kielet ja kulttuurit limittyvät ja sekoittuvat teksteissä toisiinsa.

\section{Yksikielistä tulkintaa vastaan: Zinaida Lindén}

Ruotsiksi ja venäjäksi kirjoittava Lindén on tunnetuin ja palkituin venäjänkielinen Suomessa asuva nykykirjailija, ja hän on venäjänkielisten nykykirjailijoiden joukossa ainutlaatuinen, koska hän kirjoittaa ruotsiksi. ${ }^{10}$ Suomessa ja myös muualla asuvien venäjänkielisten kirjailijoiden keskuudessa Lindén on poikkeuksellinen, sillä hän on julkaissut miltei kaikki kaunokirjalliset teoksensa kahdella kielellä, ruotsiksi ja venäjäksi. Poikkeuksellinen hän on siirtolaiskirjailijoiden joukossa myös siksi, että hän ei kirjoita toisessa kotimaassaan enemmistön puhumalla kielellä. Lindén on syntynyt vuonna 1963 Leningradissa, ja hän on opiskellut ruotsin kieltä ja kirjallisuutta Leningradin valtionyliopistossa. Hän muutti Suomeen vuonna 1991 perhesyiden vuoksi. Vuosina 1999-2000 hän asui Japanissa.

Vuodesta 1996 lähtien Lindén on julkaissut seitsemän kirjaa ruotsiksi ja viisi venäjäksi. Hänen teoksensa ovat saaneet lukuisia kirjallisuuspalkintoja Suomessa, tunnetuimpana niistä Runeberg-palkinto vuonna 2005 esikoisromaanista I väntan på en jordbävning (2004, suom. Ennen maanjäristystä 2005), jonka Lindén sai ensimmäisenä ulkomaalaistaustaisena kirjailijana. Lisäksi Lindén on kääntänyt suomenruotsalaista nykykirjallisuutta ja tietokirjallisuutta venäjäksi, ja hän kirjoittaa säännöllisesti kolumneja ja esseitä ruotsinkielisille sanoma- ja aikakauslehdille.

Lindenin romaanien ja novellien tematiikka liittyy vahvasti kulttuurienvälisyyteen, ja niissä liikutaan useiden eri kulttuurien risteyksissä ja rajamaastoissa. Teosten hahmot liikkuvat erityisesti venäläisen, suomalaisen ja suomenruotsalaisen sekä japanilaisen kulttuurin piirissä, mutta niiden tarinat liittyvät myös esimerkiksi yhdysvaltalaiseen, filippiiniläiseen, puolalaiseen ja muihin kulttuurisiin konteksteihin. Erityisesti hänen kolme romaaniaan $I$ väntan på en jordbävning (2004, suom. Ennen maanjäristystä, 2004), Takakirves-Tokyo (2007a, suom. Kirjeitä Japanista, 2007b) ja För många länder sedan (2013, suom. Monta maata sitten, 2013) käsittelevät modernia liikkuvaa elämäntapaa vieden henkilöhahmot eri puolille maailmaa. Kaksi ensimmäistä romaania sijoittuvat kolmeen maahan: Suomeen, Neuvostoliittoon tai Venäjään ja Japaniin. Ne käsittelevät venäläissyntyisen, Suomessa asuvan ja ruotsiksi kirjoittavan Iraida Dahlinin sekä Japanissa asuvan, venäläissyntyisen sumopainijan Ivan Demidovin kohtaamista ja ystävyyttä. Debyyttiromaanissa I väntan på en jordbävning, joka ilmestyi venäjäksi vuotta myöhemmin (V ožidanii zemletrjasenija, 2005), Ivan kertoo elämäntarinansa naiskirjailijalle heidän ollessaan matkalla junassa Pietarista Helsinkiin. Toisessa romaanissa, Takakirves-Tokyo, Ivanin ja naiskirjailijan tarina jatkuu sähköpostikirjeenvaihtona, kirjaimellisesti Takakirveen ja Tokion välillä, ikään kuin väliin jäävän kotimaan, Venäjän, "yli". Romaanin venäjänkielinen versio ("Po obe storony") ilmestyi 2014 Novyi mir-aikakauslehdessä. För många länder sedan (2014, ven. Mnogo stran tomu nazad, 2014) 
on minämuotoinen kertomus diplomaatin vaimosta, joka on kiertänyt maailmaa ja asettunut Suomeen. Hän käy läpi omaa lapsuuttaan Neuvostoliitossa sekä kiertävää elämäntapaansa, joka on kuljettanut hänet maasta ja kielestä toiseen, mutta ei kuitenkaan ole katkaissut hänen juuriaan. Juuret löytävät aina uuden kasvualustan säilyttäen yhteyden toisiinsa: identiteetti on kuin alati laajeneva ja uusia yhteyksiä muodostava rihmasto.

Lindénin teksteissä henkilöhahmot, jotka ovat "siirtyneet paikoiltaan", pois äidinkielestään tai kotimaastaan, joutuvat peilaamaan omaa identiteettiään ikään kuin ulkopuolelta. He kokevat uudessa kotimaassaan "toiseuttamista", heitä määritellään "toisena" suhteessa paikalliseen kieleen tai kulttuuriin, ja heihin myös kohdistetaan erilaisia toimia, joilla tätä toiseutta pyritään sulauttamaan valtakulttuuriin. Esimerkiksi romaanissa Takakirves-Tokyo naiskirjailija kokee, että hänet pyritään sulauttamaan suomenruotsalaiseen kirjallisuuteen, koska hän kirjoittaa ruotsiksi. Hän kokee kuitenkin olevansa venäläinen kirjailija, jonka koti ja kirjallinen perintö ovat venäläisessä kirjallisuudessa. Lindén kuvaa uuden kotimaan kielellä kirjoittavan kirjailijan kohtaamia stereotypioita ja ennakkokäsityksiä ironisesti. Romaanissa kirjailijan identiteetti on jatkuvasti "tuomiolla", jatkuvan tarkastelun, epäilyksen ja sen vahvistamisen rajamailla:

Kaikki haastatteluni alkavat samaan tapaan: "Iraida Dahlin on epätavallinen suomenruotsalainen kirjailija. Olethan sinä suomenruotsalainen?"

"Sinäpä sen sanot", minä vastaan kuin Jeesus Pilatukselle. (Lindén 2007b, 94.)

Vaikka muilla elämänalueilla kielten- ja kulttuurien sekoittuminen sekä monikielisyys ja -kulttuurisuus ovat arkipäivää, kirjallisuusinstituutio on kuin muusta yhteiskunnasta erillinen saareke, joka ei tunnista tai tunnusta tätä todellisuutta:

\begin{abstract}
Poliittiset ja kansalliset muurit sortuvat (...). Arvot pyyhitään pois. Rajoja hävitetään, rajoja siirretään, rajoja ylitetään. Vain kirjallisuutta tarkastellaan edelleen kapeasta kansallisesta perspektiivistä. Yhteiskunnan koneiston kaikilla muilla aloilla uudelleen arviointi on edellytys ja itsestäänselvyys - mutta kun kirjallisuudesta on kyse, kansallispuvut kaivetaan esiin. (Lindén 2007b, 263.)
\end{abstract}

Otteessa puhuu Takakirves-Tokyo-romaanin henkilöhahmo Stefan Högl, joka on Itävallasta kotoisin oleva Tokion keisarillisen yliopiston matematiikan professori. Kuvaavaa on, ettei häntä koskaan nimitetä ”japanilaiseksi matemaatikoksi", vaan "matemaatikoksi".

Lindén kuuluu siis siihen hyvin harvalukuiseen kirjailijoiden joukkoon, joka on kirjoittanut ja julkaissut kaunokirjalliset teoksensa kahdella kielellä. Kun kirjailija on itse tuottanut saman teoksen kahdella eri kielellä, herää ensiksi kysymys, kuinka se käytännössä tapahtuu. Toiseksi on kiinnostavaa kysyä, miten erikieliset versiot vaikuttavat toisiinsa tai eroavat toisistaan. Lindén luonnehtii työskentelyään seuraavasti: "Kirjoittaessani ensimmäistä versiota käytän ylipäänsä paljon assosiaatioita ja eri kieliä (esim. englantia - laulujen sanoituksia, sanontoja jne.). Sitten tuotan ensimmäisestä versiosta johdonmukaisesti kaksi rinnakkaista ja käytännössä identtistä versiota: venäjän- ja ruotsinkielisen.” (Lindén 2014b.) Tämä viittaa siihen, ettei erikielisten versioiden välillä ole selkeää rajaa, vaan ne syntyvät läheisessä yhteydessä toisiinsa. Molempiin versioihin voi liittyä kääntämistä, ja eri versiot muodostavat "kaksoisteoksen" (twin work), monikielisen kokonaisuuden (Beaujour 1989, 176; Hokenson ja Munson 2007). 
Ruotsin- ja venäjänkielisen teoksen lukeminen rinnakkain nostaa esiin elementtejä, joihin on vaikuttanut kohdekielinen lukijakunta. Venäläiseen kontekstiin liittyvät asiat voivat olla yksityiskohtaisempia venäjänkielisessä tekstissä kuin ruotsinkielisessä. ${ }^{11}$ Esimerkiksi romaanin Ennen maanjäristystä ruotsin- ja venäjänkielisessä versiossa voi huomata juuri tällaisia yksityiskohtia, kuten seuraavassa otteessa.

Tågetskakadesåvåldsamtattjagdunkadesmotväggen.Jagtänktedystertpådensömnlösanattjag hade framför mig. Ända sedan jag var liten har jag aldrig kunnat sova på tåg. (Lindén 2004, 15.)

Juna tärisi niin voimakkaasti, että iskeydyin vähän väliä seinää vasten. Ajattelin synkkänä unetonta yötä, joka minulla oli edessäni. Aivan pienestä pitäen en ole koskaan voinut nukkua junassa. (Suomennos - M.S.)

Pojezd bešeno trjassja, tak tšto menja poroi šmjakalo o stenku v kupe. S toskoi ja podumala, tšto vperedi - bessonnaja notš, sredi nemiloserdnogo stuka ljazga. S detstva mutšajus nesposobnostju spat v pojezdah. Tolko jesli pojezdka prodolžajetsja dvoje sutok ili boleje, ja izredka mogu zabytsja snom na trjasuštšeisja polke. (Lindén 2005, 13.)

Juna tärisi villisti, niin että iskeydyin välillä seinää vasten. Ajattelin synkästi, että edessäni oli uneton yö keskellä armotonta kalketta. Lapsuudesta saakka olen kärsinyt kyvyttömyydestä nukkua junissa. Vain jos matka jatkuu vähintään kaksi päivää, voin joskus vaipua uneen vaunun tärisevällä sängyllä. (Suomennos - M.S.)

Venäjänkielisessä versiossa kuvataan tarkemmin unettomuuden syytä eli kiskojen kalketta sekä viitataan pitkiin, useita päiviä kestäviin junamatkoihin, jotka Venäjällä ovat tavallisia, kun matkustetaan paikasta toiseen. Lindén toteaakin, että ruotsinkielisessä versiossa hän pyrkii "välttämään arjen yksityiskohtia ja assosiaatioita, jotka olisivat vaikeita ymmärtää ei-venäläiselle lukijalle. Tietenkin joskus jokin kohta on onnistuneempi venäjänkielisessä, joskus ruotsinkielisessä versiossa.” (Lindén 2014b.) Kiinnostavaa Lindénin tuotannossa ja sen poetiikassa on Yildizin $(2012,118)$ korostama metalingvistisyys eli tietoisuus eri kielten välisistä eroista, toisin sanoen siitä, miltä eri sanat kuulostavat eri kielillä tai miten eri kielten sanat muistuttavat toisiaan, mutta voivat tarkoittaa aivan eri asioita. Lindénin teksteissä on runsaasti koodinvaihtoa eli vieraskielisiä ilmaisuja, joita ei välttämättä selitetä tai käännetä lukijalle. Ruotsin- ja venäjänkielisessä tekstissä voi kesken virkkeen olla suomenkielinen sana, joka viittaa henkilöhahmon suomenkielisen ympäristön puhetapaan. Kielenvaihto tuo toisen kulttuurisen kontekstin näkyvästi, "kuuluvasti" ja konkreettisesti tekstiin, keskeyttämällä yhdellä kielellä aloitetun ajatuksen muunkielisellä elementillä:

Herregud, äntligen ska något som jag skrivit översättas på finska! Det kan jag visa för min granne, som jämt frågar om jag känner mig som suomalainen. (Lindén 2007a, 193, kursiivi alkutekstissä.)

Luojan kiitos, vihdoinkin jotain kirjoittamaani käännetään suomeksi! Sen voin näyttää naapurilleni, joka kysyy minulta jatkuvasti, tunnenko itseni suomalaiseksi. (Suomennos - M.S.) 
Gospodi, nakonets-to! Hot tšto-to mojo perevedut. Budet, tšto pokazat sosedu, kotoryi vsjo sprašivajet, tšuvstvuju li ja sebja "suomalainen". (Lindén 2014a.)

Hyvä luoja, vihdoinkin! Edes jotain kirjoittamaani käännetään. Onpahan jotain, mitä näyttää naapurille, joka jatkuvasti kysyy, tunnenko itseni "suomalaiseksi". (Suomennos - M.S.)

"Suomalainen" katkelmassa on lainattu "naapurin" puheesta, joka edustaa tässä asennoitumista ulkomaalaisiin ja odotusta siitä, että he assimiloituvat yhteiskuntaan ja tuntevat lopulta itsensä "suomalaisiksi". Tähän liittyy myös yksikielisyyden odotus ja stereotypia, jonka mukaan "suomalainen" kommunikoi suomeksi, eikä ruotsin kielen taito tässä (ja monessa muussa) tilanteessa auta, sillä naapuri ei puhu ruotsia. Monikielisyys ja monien kielten läsnäolo näkyy myös Lindénin novellikokoelmassa Valenciana (Lindén 2016a, suom. Rakkaus kolmeen appelsiiniin, 2016b). Kokoelmassa julkaistu novelli "En kurs i konversation" sisältää paljon puolankielisiä ilmaisuja. ${ }^{12}$ Kertomuksessa "Keskustelukurssi" kaksi maahanmuuttajaa, venäläistaustainen nainen ja puolalaistaustainen nunna, Teresa, osallistuvat suomen kielen keskustelukurssille. Kertomuksen minäkertoja, venäläistaustainen nainen, on opiskellut neuvostoaikana Puolassa, ja hän osaa vähän puolaa. Hänen aiemmat yrityksensä puhua puolaa äidinkielisten puhujien kanssa ovat kuitenkin kohdanneet jäätävän vastaanoton. Niinpä hän yllättyy iloisesti, kun Teresa alkaa mielellään puhua puolaa hänen kanssaan. Keskustelussa paljastuu, ettei Teresa puhu lainkaan englantia, sillä kommunistisessa Puolassa kaikkien koululaisten tuli opetella venäjää. Tämä aiheuttaa minäkertojassa syyllisyyden tunteen:

Olisin halunnut vajota maan alle. Historiallinen syyllisyys laskeutui harteilleni kuin lyijypeite. Oli kotimaani syytä, etteivät miljoonat Varsovan liiton varjossa kasvaneet puolalaiset olleet milloinkaan oppineet englantia. Nykypäivän maailmassa se on suunnilleen sama kuin ei tuntisi kertotaulua. Miljoonat puolalaiset kiroavat neuvostoimperialismia, imperialistista tsarismia, venäjän kieltä, vastenmielistä Puškinia, joka kirjoitti Patarouvan, sekä minua henkilökohtaisesti, olenhan miehittäjän ja sortajan jälkeläinen.

”Puolalainen ja venäläinen voivat aina ymmärtää toisiaan." Lyijypeite liukui hitaasti harteiltani.

"Totta kai. Puola ja venäjä ovat veljeskieliä", myöntelin minä diplomaattisesti. -

"Sisaruskieliä!" Lopputunnin me keskustelimme hilpeästi keskenämme. Höystimme suomea puolalaisilla lauseilla. (Lindén 2016b, 160.)

Ruotsinkielisessä versiossa ruotsin ja puolan välinen sanaleikki ruotsin kapell-sanan ("kappeli") ja puolan capella ("kamarimusiikkiyhtye") välillä aiheuttaa humoristisen sekaannuksen henkilöhahmolle. Julie Hansenin mukaan muunkieliset ilmaisut ja esimerkiksi niistä muodostetut sanaleikit voivat tuottaa erityisen lukunautinnon monikieliselle lukijalle. Ne "ylittävät yksittäisten kielten semanttiset rajat muistuttaen lukijaa siitä, että sanat eivät aina ole sitä miltä ne vaikuttavat ja ne eivät aina rajoitu vain johonkin tiettyyn kontekstiin." (Hansen 2012, 548). Edellä mainittu sanaleikki puolan ja ruotsin välillä ei toimi venäjänkielisessä versiossa, vaan vitsi täytyy selittää. Toisaalta monet puolankieliset ilmaisut tekstissä ovat niin lähellä venäjänkielisiä, ettei niitä tarvitse kääntää venäjänkieliselle lukijalle, mutta ruotsinkielisessä tekstissä ne taas täytyy kääntää: 
Tšto možet byt prekrasneje tvojego glubokogo golosa proiznosjaštšego slavjanskije slova "dlja tebja"? (Lindén 2015)

Mikä voisi olla kauniimpaa kuin sinun matala äänesi, joka lausuu slaavilaiset sanat: "sinulle" (Suomennos - M.S.)

Finns det något vackrare än din djupa altstämma som uttalar orden dla Ciebie, till dig? (Lindén 2016a, 197)

Onko mitään kauniimpaa kuin sinun matala alttosi, joka lausuu sanat dla Ciebie, sinulle?

(Suomennos - M.S.)

Monien kielten läsnäolo tekstissä ilmentää vastarintaa yksikielisyyden dominoivalle asemalle sekä muistuttaa sen rajoituksista (Wilson 2011, 137). Lindén onkin todennut, että hän haluaa vastustaa teostensa yksikielistä vastaanottoa ja tuoda esiin monikielisyyttään esimerkiksi antamissaan haastatteluissa (Lindén 2014b). Haastatteluissa ja esseissä Lindén korostaa olevansa ensisijaisesti kirjailija, joka haluaa kirjoittaa tarinoita ihmisistä (Lindén 2010; Lindén 2014b). Hän asemoi itsensä kulttuurien väliseksi "sillaksi", joka ylittää rajoja ja pyrkii teksteissään tuomaan erilaisia ihmisiä ja kulttuureita lähemmäs toisiaan (Lindén 2020, 133-134).

\section{Uuden minän synty: Polina Kopylova}

Toinen käsittelemäni venäjänkielinen kirjailija on tunnettu toimittaja Polina Kopylova, joka on kirjoittanut ja esiintynyt paljon nyky-Venäjään liittyvissä kysymyksissä. Kopylova on syntynyt 1976 Leningradissa, ja hän muutti Suomeen vuonna 2002. Hän oli julkaissut kaunokirjallisia teoksia venäjäksi jo ennen muuttoaan. Suomessa hänen runojaan ja proosatekstejään on julkaistu venäjäksi ja suomeksi LiteraruS-lehdessä ja venäjänkielisten kirjailijoiden antologioissa. Viime vuosina Kopylova on kääntänyt itse venäjänkielisiä runojaan suomeksi sekä kirjoittanut runoja sekä suomeksi että venäjäksi. Tässä artikkelissa tarkastelen hänen tuoretta kaksikielistä runokokoelmaansa Dorogije pokoiniki / Rakkaat vainajani (2018b), joka sisältää runoja rinnakkain kahdella kielellä, venäjäksi ja suomeksi. Kopylova on luonnehtinut kaksikielistä kirjallista toimintaansa samansuuntaisesti kuin muutkin kahdella kielellä julkaisseet kirjailijat: kyse ei ole kääntämisestä vaan saman idean "projisoimisesta kahdella kielellä” (Kopylova 2018a, 57).

Kopylova kommentoi, millaisia ajatuksia herättää se, että kirjailija vaihtaa äidinkielensä toiseen kieleen. Hän toteaa venäjänkielisenä joutuneensa ottamaan kantaa tiettyihin "totuuksiin", joita liittyy äidinkieleen, kotimaahan ja kirjailijan identiteettiin:

Venäläinen runoilija joutuu määrittelemään suhteensa seuraaviin käsityksiin, jotka liittyvät kieleen ja kulttuuriin: runoilija voi ilmaista itseään parhaiten vain äidinkielellä; runoilijan on välttämätöntä pitää yllä yhteyttä juuriinsa ja synnyinmaan kulttuuriin; venäläinen, joka asuu Venäjän ulkopuolella, on vapaaehtoisesti hyväksynyt jonkin peruuttamattoman menetyksen [itsessään]" (Kopylova 2018a, 57.) 
Nämä "totuudet", kuten Kopylova niitä nimittää, pätevät myös moniin muihin kieli- ja kulttuuriyhteyksiin. Hän perustelee esseessään, miksi alkoi kuitenkin kirjoittaa myös suomeksi. Suomalais-ugrilaisten kielten säilyttämä "luonnonläheisyys" ja suomen kielen rooli Kopylovan omassa elämässä vaikuttivat siihen, että kieli vaihtui venäjästä suomeen tai suomen kieli tuli venäjän rinnalle. Hän halusi myös laajentaa potentiaalista lukijakuntaansa, sillä Suomessa venäjänkielisen runouden lukijakunta on varsin pieni. (Kopylova 2018a, 58.)

Kopylovan siirtymistä kirjottamaan runoja kahdella kielellä ilmentää hänen kaksikielinen runoteoksensa Dorogije pokoiniki/Rakkaat vainajani (2018b), joka esittää samat runot kahdella kielellä, suomeksi ja venäjäksi. Tämä rinnakkaisuus mahdollistaa kaksikieliselle lukijalle runojen vertailun: runot ovat "identtisiä", mutta niiden sanasto ja ilmaisukeinot voivat erota toisistaan:

\footnotetext{
Pyrin nimenomaan siihen, että tekstini purisi kumpaankin yleisöön samalla teholla ja välittäisi samoja universaalisia ajatuksia kummallekin yleisölle, joten kiinnitän huomioni enimmäkseen siihen, että suomenkielisen ja venäjänkielisen version merkitykset olisivat mahdollisimman lähellä toisiaan tai parhaassa tapauksessa identtisiä. (Kopylova 2019.)
}

Teoksen teemana on kuolema ja siihen liittyvät kulttuuriset merkitykset ja erot sekä uudelleen syntyminen. Uuden kielen omaksumista on kuvattu uuden minän ja identiteetin syntymisenä: subjekti, "minä”, opettelee uudelleen puhumaan ja käyttämään kieltä, ja samalla hän oppii myös uudenlaisen tavan hahmottaa ympäröivää maailmaa uuden kielen rakentamana, sen subjektina ja sen kautta. "Kuolema" ja "vainajat" merkitsevät siis metaforisesti vanhan kielen, minän ja niiden kulttuuriseen ympäristöön liittyvien asioiden hyvästelyä:

\footnotetext{
Toisen itsensä synnytys on samalla edellisen itsensä menettämistä - mukana omakuva, haaveet, näkemykset, ystävyydet ja viholliset. Jopa kuoleman pelko. Minulla oli jo pitkään ajatus kunnioittaa näitä elämäni vainajia - sisäisiä ja ulkoisia, läheisiä ja lähes tuntemattomia, kuolleita ja näköpiiristäni hävinneitä - kertomalla heistä sen, mitä parhaiten muistan. Ja koska olen kielellisesti ikään kuin kahdesti syntynyt - kerron kahdella kielellä. Kyseessä ei siis ole käännös - vaan suora kerronta, kuin muistotilaisuudessa. (Kopylova 2018b, 5.)
}

Tämä ote Kopylovan esipuheesta hänen kaksikieliseen teokseensa keskustelee muiden kaksikielisten teosten ja kahdella kielellä kirjoittavien kirjailijoiden näkemysten sekä alan tutkimusten kanssa. Gentes $(2013,268-269)$ tuo esiin kaksikielisen julkaisemisen "parantavan voiman": kahdella kielellä kirjoittava voi tuoda esiin oman identiteettinsä ikään kuin "kokonaisena", molemmilla kielillä yhtä aikaa, ja tehdä näkyväksi oman monikielisen toimijuutensa ja luovuutensa. Wanner $(2018,129)$ esittää kiinnostavasti, että "kaksikielisen, rinnakkaisten tekstien korpuksen luominen on keino ommella yhteen harsuuntunut, kaksikulttuurinen identiteetti”.

Kopylovan teos Dorogije pokoiniki/Rakkaat vainajani jakautuu osiin, jotka on nimetty henkilön kuoleman jälkeen jääneiden läheisten näkökulmasta: Opis nasledujemogo - Perunkirja, Pominki - Muistotilaisuus, Zaveštšanije - Testamentti. Osat ja niiden otsikot nimeävät prosessia, jonka aikana vainajia muistellaan, hyvästellään ja kuullaan heidän viimeinen tahtonsa. Teoksessa tämä prosessi on sekä kuvaannollinen että konkreettinen: runojen minän kautta kirjailija Kopylova tarkastelee kaksikielistä identiteettiään. Samalla kirjailijan yksikielinen identiteetti jää taka-alalle, se on "edellisen itsensä menettämistä" (Kopylova 2018b, 5). 
Teoksen runoissa tartutaan Suomen ja Venäjän välisiin kulttuuri-ja kielieroihin, jotka liittyvät kuolemaan ja kuolemiseen, kuten vainajan saattamiseen hautaan ja hänen muistelemiseensa. Kopylova on todennut esseessään, että "suomeksi surunvalitteluja ei ilmaista tai tuoda, vaan he [suomalaiset] ottavat osan (surusta) itselleen. Tällainen idiomi voi tehdä sen siirtämisestä venäjänkieliseen tekstiin vaikeaa.” (Kopylova 2018a, 59.) Seuraavassa runokatkelmassa näemme, miten Kopylova luo tästä kielikuvasta oman tulkintansa, jonka hän on välittänyt myös venäjänkieliseen tekstiin:

\author{
na treti den pritupljaetsja bol \\ na devjatyi otpuskaetsja toska \\ na sorokovoi tšuvstvo gorja stanovitsja tšastju tebja - \\ i boleje ne trebujet nitšjego sotšuvstvija. (Kopylova 2018b, 54.) \\ kolmantena päivänä kipu vaimenee \\ yhdeksäntenä tuska hellittää \\ neljäntenäkymmenentenä surun tunne tulee osaksi sinua - \\ eikä enää vaadi kenenkään myötätuntoa (Suomennos - M.S.)
}

Kopylovan suomenkielinen versio runosta välittää saman ajatuksen hieman eri ilmaisuin:

\author{
kolmantena päivänä hautajaistouhuissa hellittää terävin kipu \\ yhdeksäntenä rauhoittuu suurin kaipuu \\ neljäntenäkymmenentenä surusta tulee osa \\ elämääsi, eikä muiden enää tarvitse sitä osaa sinulta ottaa. (Kopylova 2018b, 55.)
}

Tässä säkeistössä suomenkielinen ilmaisu ottaa osaa suruun on vaikuttanut venäjänkieliseen versioon: "tšuvstvo gorja stanovitsja tšastju tebja" - surun tunne tulee osaksi sinua. Säkeistössä leikitellään suomenkielisellä kielikuvalla: suomen idiomi on ikään kuin purettu osiinsa. Suomenkielisessä versiossa käytetään samaa ilmaisua sen suorassa merkityksessä: "surusta tulee osa elämääsi, eikä muiden enää tarvitse sitä osaa sinulta ottaa". Venäjänkielisessä versiossa myös sanat tšastju ("osa"), tšuvstvo ("tunne") ja sotšuvstvija ("myötätunto") sointuvat toistensa kanssa: "tšuvstvo gorja stanovitsja tšastju tebja / i boleje ne trebujet nitšjego sotšuvstvija" (neljäntenäkymmenentenä surun tunne tulee osaksi sinua / eikä enää vaadi kenenkään myötätuntoa). Suomenkielisessä versiossa sanotaan: "surusta tulee osa / elämääsi, eikä muiden enää tarvitse sitä osaa sinulta ottaa". Molemmissa versioissa kielten ilmaisuja venytetään ja kielten välille rakentuu yhteys, jonka kaksikielinen lukija voi havaita. Tämä kielten limittyminen ja toisiinsa kurkottaminen on mielestäni Kopylovan runotekstien ytimessä.

Kopylova ei runoteksteissään käytä yhtä runsaasti muunkielisiä ilmaisuja kuin Lindén proosateksteissään. Monikielisyyden korostus on kuitenkin ilmeistä, kun runot on aseteltu molemmilla kielillä rinnakkain. Myös metalingvistisyys on olennainen osa Kopylovan poeettista ilmaisua, kuten edellä mainittu esimerkki kielikuvasta osoittaa. Runoissa myös tarkastellaan sanoja foneettisina merkkeinä, esim: 
Me-ta-fo-ra.

A-fo-ra-tem.

Sopii nimeksi jollekin

tulevan kirjani hahmolle.

Kirja joskus julkaistaan. Vielä

M. Tsvetajeva sanoi, että kaikki

julkaistaan. Jopa nämä säkeet. (Kopylova 2018b, 13.)

Runossa sana "metafora" on käännetty melkein nurinpäin. Kun sanat käännetään nurinpäin, ne eivät tarkoita mitään vaan "vapautuvat" fiktiiviseen käyttöön, jolloin ne saavat uuden merkityksen. Tulkitsen tämän viittaavan paitsi kirjailijan kykyyn luoda uusia sanoja, uusia merkityksiä ja ilmaisuja, myös muulla kuin äidinkielellä kirjoittavan runoilijan kykyyn nähdä uudessa kielessä uusia mahdollisuuksia, vaikka ne eivät aina olisikaan kieliopillisesti oikein tai aivan idiomaattisia. Esimerkiksi tämän katkelman suomenkieliseen versioon, joka on identtinen venäjänkielisen kanssa (Kopylova 2018b, 12), on vaikuttanut selkeästi venäjän ilmaisutapa: "Vielä / M. Tsvetajeva sanoi,..." on venäjän kielestä ("Ještšo / M. Tsvetajeva skazala,...") suoraan tehty käännös, mitä voi pitää interferenssinä eli toisen kielen vaikutuksena, sillä idiomaattinen suomenkielinen ilmaisu olisi "jo M. Tsvetajeva sanoi". Tämä virhe voi olla tietoista, vieraannuttavaa kielenkäyttöä, kuten Wanner $(2018,124)$ on todennut tarkastellessaan englanniksi kirjoittavien venäjänkielisten kirjailijoiden tekstejä: se on merkki siitä, ettei kieli ole "oma", vaan se on tekstissä kuuluva "aksentti".

Kopylova on esseessään $(2018 \mathrm{a}, 59)$ kommentoinut suomen ja venäjän kielen välisten ilmaisujen eroja ja niiden tuomia haasteita kahdella kielellä kirjoittamiseen. Tärkein edellytys "runotekstin syntymiseen kahdella kielellä" on tunneside toiseen kieleen, koska se antaa vapauden luoda omia rakenteita ja merkitysten nyansseja. On kuitenkin oltava rohkeutta sietää virheitä, joita vieraalla kielellä kirjoittaessa tulee.

Kiinnostava on kokoelman runojen asettelu niin, että venäjänkielinen runo tulee ensin ja suomenkielinen sen jälkeen - tätä havainnollistaa myös runoteoksen sisällysluettelo. Tämän voi tulkita joko niin, että venäjänkieliset runot ovat syntyneet ensin ja sitten suomenkieliset, minkä kirjailija esipuheessaan kuitenkin torjuu: kyse ei ole käännöksestä, vaan "suorasta puheesta" kahdella kielellä. Sen voi tulkita kuvastavan myös sitä, että venäjänkielinen on saanut rinnalleen suomenkielisen: se kuvaa identiteetin muuttumista ajassa. Uudella ja kahdella kielellä kirjoittaminen on muistamisprosessi, jossa omaelämäkerrallinen pohdinta uuden kielen ja uuden "minän" omaksumisesta edellyttää välttämättä unohtamista ja aiemman kielen, kulttuurin ja itsensä muuttamista joksikin muuksi (Seyhan 2001, 92).

\section{Ylirajaisuuden mahdollisuudet}

Olen artikkelissani tarkastellut ylirajaisen, muulla kuin kirjoittajan äidinkielellä kirjoitetun kirjallisuuden herättämiä ajatuksia identiteetistä, kielestä ja kirjallisuudesta sekä johdattanut lyhyesti kahden venäjänkielisen Suomessa asuvan kirjailijan ajatuksiin kaksikielisestä luomisprosessista. Kahdella kielellä julkaiseminen ja tekstien lähes samanaikainen tuottaminen eri kielillä osoittaa nykykirjailijoiden kyvyn ja halun edistää monikielisyyttä, monikulttuurisuutta ja kulttuurienvälisyyttä - yhteyttä erillisyyden sijaan. Tekstien ja identiteettien rinnakkaisuus, limittäisyys ja sekoittuminen onkin ominaista Lindénin ja Kopylovan kaltaisille kirjailijoille, 
jotka kokevat olevansa välittäjiä ja joille on tärkeää kertoa tarinoita ja välittää merkityksiä eri kielillä, kuten molemmat ovat ilmaisseet haastatteluissaan ja kirjoituksissaan. Ylirajaisia kirjailijoita, jotka tuntevat kuuluvaansa kahteen tai useampaan kotimaahan, kieleen ja kulttuurin, ja jotka toimivat useassa roolissa kielten välillä - toimittajina, kirjailijoina, kääntäjinä - on vaikea "sovittaa kansallisten kirjallisuuksien kehyksiin" (Parente-Čapková 2017, 41). Kirjallisuuden tarkastelu kapeasta kansallisesta näkökulmasta häivyttää monikielisyyttä ja ylirajaisten kirjailijoiden toimijuutta. Maailmassa, jossa "ylirajaistuminen" ja monikielisyys ovat arkipäivää, kirjallisuudentutkijoiden on tärkeää tarkastella "miksi ja millä perusteella kielellisiä ja esteettisiä rajoja rakennetaan, rikotaan ja rakennetaan uudelleen" (Kauranen, Huss \& Grönstrand 2020, 20). Tutkijat ovatkin viime aikoina alkaneet tarkastella myös Venäjän kirjallisuushistoriaa monikielisyyden ja ylirajaisuuden näkökulmista (ks. Hansen 2019; Leiderman 2015; Wanner 2019). Lindénin ja Kopylovan tekstit osoittavat, että monikielisyys ja ylirajaisuus ovat tärkeä osa nykykirjailijoiden tapaa luoda kaunokirjallisia tekstejä ja hahmottaa omaa identiteettiään kirjailijoina maailmassa.

\section{Viiitteet}

1 Ylirajaistumisella viittaan tässä prosesseihin, joissa "globaali, transnationaalinen ja kansalliset kirjalliset elämät sekä niin ihmisten ja kirjallisuudenkin liikkuvuus kuin erilaiset paikallisuudet kietoutuvat monisyisellä tavalla yhteen" (Nissilä 2016, 15).

2 Tämä artikkeli on osa tutkimusprojektia "Tekstit liikkeessä: naiskirjailijoiden tuotannon vastaanotto Suomessa ja Venäjällä 1840-2020" (Emil Aaltosen säätiö), www.tekstitliikkeessa.com.

3 Monikielisyys, hybridit identiteetit, diaspora, ylirajaisuus ja välitila ovat käsitteinä kehittyneet ja vakiintuneet postkoloniaalisessa kirjallisuudentutkimuksessa (Steinitz 2013, 4).

4 Kaikki käännökset tutkimuskirjallisuudesta ovat tämän artikkelin kirjoittajan.

5 Adrian Wanner (2011) ja Eva Hausbacher (2009) ovat julkaisseet aiheesta monografian. Lisäksi viime vuosina on julkaistu runsaasti venäläistä ylirajaista kirjallisuutta käsitteleviä artikkeleita, mm. Finkelstein 2014; Hansen 2012, 2018; Klapuri 2012a, 2012b, 2016; Lebedeva \& Lupatševa 2019; Sorvari 2016, 2018a, 2018b.

6 Tilanne oli samankaltainen Saksassa, jossa emigroituneet venäläiset kirjailijat eivät syystä taikka toisesta osallistuneet saksalaiseen kulttuuri-, kirjallisuus- tai poliittiseen elämään (Finkelstein 2014, 369).

7 Katsaus venäjänkielisten nykykirjailijoiden toimintaan, ks. Sorvari (2018a). Ljudmila Kol on koonnut ja toimittanut kaksi venäjänkielisten kirjailijoiden suomennosta: Missä hongat humisevat (2006) ja Huhupuheita (2013). Venäjänkielisten kirjailijoiden tekstejä on ilmestynyt myös suoraan käännöksinä: Inna Latiševan Ryssänä Suomessa. Vieras väärästä maasta (2010) ja Inna Patrakovan romaanit Tulkki (2010), Naapurit (2011) ja Kultahammas (2012) ovat ilmestyneet suoraan käsikirjoituksesta suomennettuina teoksina.

8 Tutkijat ovat käyttäneet myös nimitystä "kielisiirtolainen" (language migrant) (Besemeres 2002; Wilson 2011). 
9 Tätä ajatusta ei pidä tulkita siten, etteikö yksilöllä olisi oikeutta käyttää ja puhua nimenomaan äidinkieltään (vrt. Latomaa 2010), vaan kyse on kirjailijan työstä, jossa kieli on työväline ja jossa kirjailija voi tuoda esiin näkemyksiä muun muassa kielistä sekä niiden välisistä jännitteistä ja valta-asetelmista (vrt. Grönstrand 2016, 51-52).

10 Aiempiakin esimerkkejä toki on: yksi varhaisimmista ruotsiksi kirjoittaneista venäjänkielisistä kirjailijoista oli Suomen autonomisessa ruhtinaskunnassa elänyt Marie Linder (1840-1870, neé Musin-Puškin) (Launis 2005). Myös emigranttirunoilija Vera Bulitš (1898-1954), kirjoitti joitakin kaunokirjallisia tekstejä ruotsiksi (Baschmakoff \& Leinonen 2001).

11 Ks. myös Lindénin kuvaus omasta kirjoitusmetodistaan: Lindén 2020, 134-136.

12 Kertomus on ilmestynyt ensin venäjäksi, "Kurs razgovornogo jazyka" (2015, suom. "Keskustelukurssi”).

\section{Lähteet}

Apter, Emily (2006), The Translation Zone. A New Comparative Literature. Princeton \& Oxford: Princeton University Press.

Baschmakoff, Natalia \& Marja Leinonen (2001), Russian Life in Finland 1917-1939. A Local and Oral History. Studia Slavica Finlandensia XVIII. Helsinki: IREES.

Beaujour, Elisabeth Klosty (1989), Alien Tongues: Bilingual Russian Writers of the "First" Emigration. Ithaca: Cornell University Press.

Besemeres, Mary (2002), Translating One's Self: Language and Selfhood in Cross-Cultural Autobiography. Oxford: Peter Lang.

Finkelstein, Miriam (2014), A Common Place, a Contested Space: Reciprocal Representations of Russian and Eastern European Migrants in their Berlin Narratives. - Zeitschrift für Slavische Philologie 70:2, 365-400.

Fitch, Brian T. (1988), Beckett and Babel: An Investigation into the Status of the Bilingual Work. Toronto: Toronto University Press.

Gentes, Eva (2013), Potentials and Pitfalls of Publishing Self-Translations as Bilingual Editions. Orbis Litterarum 68:3, 266-281.

Grutman, Rainier (2009), Self-Translation. - Routledge Encyclopedia of Translation Studies. Eds. Mona Baker \& Gabriela Saldanha. 2nd ed. London \& New York: Routledge, 257-260.

Grutman, Rainier \& Trish Van Bolderen (2014), Self-Translation. - A Companion to Translation Studies. Eds. Sandra Berman \& Catherine Porter. Chichester: Wiley-Blackwell, 323-332.

Grönstrand, Heidi (2014), Self-translating: Linking Languages, Literary Traditions and Cultural Spheres. - Cosmopolitanism and Transnationalism: Visions, Ethics and Practices. Ed. Leena Kaunonen. Helsinki: Helsinki Collegium for Advanced Studies, 116-137, https://helda.helsinki. fi/handle/10138/45246 (Tarkistettu 22.2.2020).

Grönstrand, Heidi (2016), Kirjallisuushistoria, kansakunta ja kieli. Monikielisyys metodologisen nationalismin haasteena. - Kansallisen katveesta. Suomen kirjallisuuden ylirajaisuudesta. Toim. Heidi Grönstrand, Ralf Kauranen, Olli Löytty, Kukku Melkas, Hanna-Leena Nissilä \& Mikko Pollari. Helsinki: SKS, 38-59.

Grönstrand, Heidi, Ralf Kauranen, Olli Löytty, Kukku Melkas, Hanna-Leena Nissilä \& Mikko Pollari (2016), Johdanto. Ylirajainen kirjallisuudentutkimus ja deterritorialisoiva lukutapa. - Kansallisen katveesta. Suomen kirjallisuuden ylirajaisuudesta. Toim. Heidi Grönstrand, Ralf Kauranen, Olli Löytty, Kukku Melkas, Hanna-Leena Nissilä \& Mikko Pollari. Helsinki: SKS, 7-37. 
Hansen, Julie (2012), Making Sense of the Translingual Text: Russian Wordplay, Names, and Cultural Allusions in Olga Grushin's The Dream Life of Sukhanov. - Modern Language Review 107:2 , 540-558, DOI: 10.5699/modelangrevi.107.2.0540.

Hansen, Julie (2018), Introduction: Translingualism and transculturality in Russian contexts of translation. - Translation Studies 11:2, 113-121, DOI: 10.1080/14781700.2018.1434087.

Hansen, Julie (2019), Reading War and Peace as a Translingual Novel. - Polylinguality and Transcultural Practices/ Polilingvalnost i transkulturnyje praktiki 16:4, 608-621, DOI 10.22363/2618897X-2019-16-4-608-621.

Hokenson, Jan Walsh \& Marcella Munson (2007), The Bilingual Text. History and Theory of Literary Self-Translation. Manchester: St. Jerome Publishing.

Kauranen, Ralf, Markus Huss \& Heidi Grönstrand (2020), Introduction. The Processes and Practices of Multilingualism in Literature. - The Aesthetics and Politics of Linguistic Borders: Multilingualism in Northern European Literature. Eds. Heidi Grönstrand, Markus Huss \& Ralf Kauranen. New York: Routledge, 3-23.

Kellman, Steven G. (2000), The Translingual Imagination. Lincoln, NE: University of Nebraska Press.

Klapuri, Tintti (2012a), Kolmannesta aallosta neljänteen. - Kenen aika. Esseitä venäläisestä nykykirjallisuudesta. Toim. Tomi Huttunen \& Tintti Klapuri. Helsinki: BTJ, 369-377.

Klapuri, Tintti (2012b), Matkalla ei-kenenkään maassa: Zinaida Lindén. - Kenen aika. Esseitä venäläisestä nykykirjallisuudesta. Toim. Tomi Huttunen \& Tintti Klapuri. Helsinki: BTJ, 401-410.

Klapuri, Tintti (2016), Literary St. Petersburg in Contemporary Russian Transnational Writing. Anya Ulinich, Gary Shteyngart, and Zinaida Lindén. - Scando-Slavica 62:2, 235-248, DOI: 10.1080/00806765.2016.1257771.

Kopylova, Polina (2018a), Samoperevod v poezii: opyt marginalnoi tvortšeskoi praktiki. - LiteraruS - literaturnoje slovo 3/2018, 57-59.

Kopylova, Polina (2018b), Dorogije pokoiniki / Rakkaat vainajani. Tšerboksary, Nižni Novgorod: Free poetry.

Kopylova, Polina (2019), suomenkielinen sähköpostihaastattelu tekijän kanssa, 10.9. 2019.

Latomaa, Sirkku (2010), "Hänellä ei ole kieltä missä hän voisi elää" - kirjallisuus kielipolitiikan ilmentäjänä. - Vähemmistöt ja monikulttuurisuus kirjallisuudessa. Toim. Eila Rantonen. Tampere: Tampere University Press, 40-68.

Launis, Kati (2005), Kerrotut naiset. Suomen ensimmäiset naisten kirjoittamat romaanit naiseuden määrittelijöinä. Helsinki: SKS.

Lebedeva, Jekaterina . S. ja Lupatševa, Tatjana A. (2019), Sravnitelnyi analiz lingvostilistitšeskih osobennostei tvortšestva pisatelei-translingvov. - Polylinguality and Transcultural Practices/Polilingvalnost i transkulturnyje praktiki 16:3, 347-57, DOI 10.22363/2618-897X-2019-16-3-347-357.

Leiderman, Naum L. (2015), Russkojazytšnaja literatura - perekrjostok kultur. - Filologitšeski klass 3, 19-24, http://elar.uspu.ru/handle/uspu/2466 (Tarkistettu 21.2. 2020).

Lindén, Zinaida (2007a), Takakirves-Tokyo. Brevroman. Helsinki: Söderströms.

Lindén, Zinaida (2007b), Kirjeitä Japanista. Käsikirjoituksesta suom. Jaana Nikula. Helsinki: Gummerus.

Lindén Zinaida (2010), Att leva och skriva globalt i Svenskfinland. - LiteraruS - Literaturnoje slovo 6/2010, http://www.literarus.org/arkiv/swe2010/swe6d_2010.php (Tarkistettu 20.2.2020).

Lindén, Zinaida (2014a), Po obe storony. Novyi mir, 7, https://magazines.gorky.media/novyi_mi/2014/7/ po-obe-storony.html (Tarkistettu 21.2. 2020).

Lindén, Zinaida (2014b), venäjänkielinen sähköpostihaastattelu tekijän kanssa, 22.5. 2014.

Lindén, Zinaida (2015), Kurs razgovornogo jazyka. Zinziver 8, https://magazines.gorky.media/ zin/2015/8/rasskazy-438.html (Tarkistettu 21.2.2020).

Lindén, Zinaida (2016a), Valenciana. Noveller. Helsinki: Schildts \& Söderströms.

Lindén, Zinaida (2016b), Rakkaus kolmeen appelsiiniin. Suom. Jaana Nikula. Helsinki: Into.

Lindén, Zinaida (2020), An Author's View: To Be a Bridge Between Cultures. - The Aesthetics and Politics of Linguistic Borders. Multilingualism in Northern European Literature. Eds. Heidi Gröndstrand, Markus Huss and Ralf Kauranen. New York: Routledge, 130-138.

Nissilä, Hanna-Leena (2016), ”Sanassa maahanmuuttaja on vähän kitkerä jälkimaku”. Kirjallisen elämän ylirajaistuminen 2000-luvun alun Suomessa. Oulu: Oulun yliopisto.

Nordin, Irene Gilsenan, Julie Hansen \& Carmen Zamorano Llena (eds.) (2013), Transcultural Identities in Contemporary Literature. Amsterdam: Brill Academic Publishers. 
Parente-Čapková, Viola (2017), Naisten kirjoittaman kirjallisuuden ylirajainen vastaanotto. Kohti kirjallisten toimijuuksien historiaa. - Kirjallisuudentutkijoiden aikakauslehti Avain 4/2017, 36-49.

Seyhan, Azade (2001), Writing Outside the Nation. Translation/Transnation. Princeton, NJ.: Princeton University Press.

Sorvari, Marja (2016), “On Both Sides”: Translingualism, Translation, and Border-Crossing in Zinaida Lindén's Takakirves-Tokyo. - Scando-Slavica 62:2, 141-159, DOI: 10.1080/00806765.2016.1257766.

Sorvari, Marja (2018a), Altering language, transforming literature: Translingualism and literary self-translation in Zinaida Lindén's fiction. - Translation Studies 11:2, 158-171, DOI: 10.1080/14781700.2017.1399820.

Sorvari, Marja (2018b), Native, foreign, translated? 'Russian' Migrant Literature between Finland and Russia. - Migrants and Literature in Finland and Sweden. Eds. Satu Gröndahl \& Eila Rantonen. Helsinki: Finnish Literature Society. https://oa.finlit.fi/site/books/10.21435/sflit.11/ (Open access).

Steinitz, Tamar (2013), Translingual Identities. Language and the Self in Stephan Heym and Jakov Lind. New York: Camden House.

Wanner, Adrian (2011), Out of Russia: Fictions of a New Translingual Diaspora. Evanston, IL: Northwestern University Press.

Wanner, Adrian (2013), Lolita and Kofemolka: Vladimir Nabokov's and Michael Idov's Self-Translations from English into Russian. - Slavic and East European Journal 57:3, 450-464

Wanner, Adrian (2018), The poetics of displacement: Self-translation among contemporary RussianAmerican poets. - Translation Studies 11:2, 122-138, DOI: 10.1080/14781700.2017.1336641.

Wanner, Adrian (2019), A Forgotten Translingual Pioneer: Elizaveta Kul'man and Her Self-translated Poetry. - Polylinguality and Transcultural Practices/ Polilingvalnost $i$ transkulturnyje praktiki 16:4, 562-574, DOI 10.22363/2618-897X-2019-16-4-562-579

Wilson, Rita (2011), Cultural Mediation through Translingual Narrative. - Target 23:2, 235-250.

Yildiz, Yasemin (2012), Beyond the Mother Tongue: The Postmonolingual Condition. Modern Language Initiative. New York: Fordham University Press. 